IFN Working Paper No. 766, 2008

\title{
Entrepreneurship and Second-best Institutions: Going Beyond Baumol's Typology
}

Robin Douhan and Magnus Henrekson 


\title{
Entrepreneurship and Second-best Institutions: Going Beyond Baumol's Typology*
}

\author{
Robin Douhan ${ }^{1,2}$ and Magnus Henrekson ${ }^{1+}$
}

12 March 2010

\begin{abstract}
This paper reconsiders the predominant typology pioneered by Baumol (1990) among productive, unproductive and destructive entrepreneurship. It is shown that the foundation of Baumol's classificatory scheme is the restrictive concept of first-best outcomes, and therefore it easily fails to appreciate the true impact of entrepreneurship in real world circumstances characterized by suboptimal institutions. We present an alternative way of generalizing the notion of entrepreneurship and show how and why it encompasses the Baumol typology as a special case. Our main distinction is between business and institutional entrepreneurship. We draw on Schumpeter and introduce the entrepreneur in an additional function: as a potential disturber of an institutional equilibrium. Various subsets of institutional entrepreneurship are posited and discussed. It is shown that changing the workings of institutions constitutes an important set of entrepreneurial profit opportunities. An implication of this is that entrepreneurial efforts to reform or offset inefficient institutions can in many cases be welfare-improving.
\end{abstract}

JEL Codes: L5; M13; O31; O17.

Keywords: Entrepreneurship; Innovation; Institutions.

† Corresponding author

${ }^{1}$ Research Institute of Industrial

Economics (IFN)

Box 55665

SE-102 15 Stockholm

Phone: +46-8-665 4500

Fax: +46-8-665 4599

e-mail: magnus.henrekson@ifn.se

\author{
${ }^{2}$ Department of Economics \\ Uppsala University \\ Box 513 \\ SE-751 20 Uppsala
}

\footnotetext{
* Robin Douhan sadly passed away on August 10, 2009. His friendship, kindness and talent will be deeply missed. Financial support from the Gustaf Douglas Research Program on Entrepreneurship at IFN and from the Jan Wallander and Tom Hedelius Research Foundation is gratefully acknowledged. We thank Aron Berg, Niclas Berggren, Dan Johansson, Henrik Jordahl, Erik Lindqvist and Tino Sanandaji for useful comments and suggestions on an earlier version of this paper.
} 


\section{Introduction}

Just two decades ago, the received view was that economic growth is caused by the accumulation of factors of production. In his seminal contributions, Douglass North (e.g., 1990) claimed that this is merely a proximate cause of growth, the ultimate causes residing in the incentive structure that encourages individual effort and investment in physical and human capital and in new technology. This incentive structure is in turn determined by "the rules of the game in society" or the institutional setup. The role of institutions has, in recent years, reemerged as a dominant mainstream explanation of long-term economic performance (e.g., Rodrik et al. 2004; Acemoglu et al. 2005).

William Baumol (1990) was a pioneer in examining the role of institutions in entrepreneurial behavior and analyzing the way in which "the social structure of payoffs" channels entrepreneurial talent to different activities - which may be productive, unproductive or destructive. He assumed the supply of entrepreneurial talent to be roughly constant, and thus that the rate of growth is largely determined by its distribution across the three types of entrepreneurship, which is in turn determined by the institutional setup.

Baumol's (1990) typology dividing entrepreneurial activities into productive, unproductive and destructive forms has proven to be an intuitive and appealing way of expanding the set of activities that require entrepreneurial talent (see, e.g., Minniti 2008). It has played an invaluable role in highlighting the role of institutions and accelerated our understanding of the growth and welfare effects of entrepreneurial activity. Recently, the typology has been especially influential as research has sought to dig deeper into the particularities of unproductive and destructive entrepreneurship. It is, therefore, important to examine more closely the assumptions on which his theory rests.

Baumol (1990) focuses primarily on institutions as an allocation device. However, analyzing institutions solely as allocation devices overlooks the fact that the institutional framework within which an activity is performed often determines whether this activity is productive, unproductive or destructive. In particular, what appears to be an unproductive activity may in many circumstances be a second-best substitute for inefficient institutions. 
Provision of second-best substitutes is an important instance of a more general set of phenomena in which entrepreneurial activities change the workings of the institutional setup. This partly obfuscates the role of institutions as an allocation mechanism by creating an analytical circularity. How can the structure of rewards that allocates talent itself be determined by the application of this talent? One way out of this dilemma is to acknowledge that institutions become targets for entrepreneurial innovativeness because changing their workings is a means of earning or enhancing entrepreneurial profit.

There is a strong possibility of earning profit by changing the way formal institutions affect other agents, particularly when current institutions are costly for productive activities. By relaxing institutional restrictions on productive entrepreneurship, these efforts may be welfare-improving, even though they are driven mainly by individuals' incentives to earn profit.

We build on this insight to extend the concept of entrepreneurship in a novel way, going beyond purely business related activities. As with Baumol's typology, our proposal goes back to Schumpeter (1934). In contrast to Baumol, who defines the entrepreneurial function exclusively in terms of Schumpeter's notion of entrepreneurship as innovative combinations, we assign the additional function of disturbing an equilibrium to the entrepreneur.

We propose a typology consisting of business entrepreneurship and institutional entrepreneurship. The allocation between these types is determined by potential rewards embedded in the existing institutional setup and in the production system. The two types of entrepreneurship disturb, respectively, the production system and the institutional equilibrium. An activity that disturbs the institutional equilibrium could be a novel welfare-improving second-best substitute for inefficient institutions, but may also reduce welfare. Baumol's typology is shown to fit nicely into our new proposal as a special case in which the welfare consequences of the activity at hand are known ex ante.

The next section outlines the most important features of Baumol (1990) and the manner in which the literature has evolved. Section 3 sheds light on some subtle limitations of Baumol's typology and the preconditions for its application. In Section 4, we make a case for our own contribution and discuss how it extends Baumol's theory. The concluding section offers a summary and looks forward to further work. 


\section{Baumol's typology}

Baumol's analysis represents an essential step in bringing institutions to the fore of the analysis of the role of entrepreneurship in economic development. By referring to basic microeconomic assumptions, it is hypothesized that core entrepreneurial talents - such as creativity, alertness and the ability to get things done - are used to maximize individual utility, not social welfare. It then follows that entrepreneurship is not necessarily welfare enhancing.

Baumol's analysis rests on two premises. First, he assumes entrepreneurial talent is reasonably equally distributed across time and societies, but that its manifestation crucially depends on the institutional setup. ${ }^{1}$ Second, he follows Schumpeter and defines the entrepreneurial function as the carrying out of new combinations. Baumol (1990, p. 897) presents his theory as an extension of Schumpeter's five types of combinations: ${ }^{2}$

To derive more substantive results from an analysis of the allocation of entrepreneurial resources, it is necessary to expand Schumpeter's list, whose main deficiency seems to be that it does not go far enough [...] Schumpeter's list of entrepreneurial activities can usefully be expanded to include such items as innovations in rent-seeking procedures, for example, discovery of a previously unused legal gambit that is effective in diverting rents to those who are first in exploiting it.

Based on this extension, Baumol builds a typology of productive, unproductive and destructive entrepreneurship. The classification of activities into one of these three types depends on several criteria: Do they increase overall productivity? Do they entail a redistribution that leaves overall productivity unaffected, or do they reduce it? Those who have referred to Baumol have often explicitly interpreted this as positive, zero and negative shifts of the production possibility frontier (e.g., Coyne and Leeson 2004). What is noteworthy here is that, clearly, an activity cannot be properly assigned to one of the categories until its effect on productivity has been determined.

The strong conclusion that emerges from this analysis is that inefficient institutions not only forgo opportunities for social benefit by hampering productive entrepreneurship, but that they may as well direct entrepreneurial talent towards activities that reduce aggregate productivity and social welfare. This has naturally been seen as an important contribution to the literature

\footnotetext{
${ }^{1}$ This idea was concurrently pursued with respect to managerial talent by Murphy, Shleifer and Vishny (1991).

${ }^{2}$ According to Schumpeter (1934, p. 66), entrepreneurial activities can consist of the: (i) introduction of a new good (or a new quality of a good); (ii) introduction of a new method of production; (iii) opening of a new market; (iv) conquest of a new source of supply of raw materials or semi-manufactured goods; and (v) implementation of a new organizational form.
} 
on long-term growth (e.g., Hall and Jones 1999; Jones 2001). Micro-oriented studies have explored the implications of the allocation of talent (e.g., Acemoglu 1995; Baumol 1993, 2002). Recently, some interest has been focused on the particularities of the unproductive and destructive forms of entrepreneurship. For example, Desai and Acs (2007) sketch a theory that addresses occurrences of destructive entrepreneurship, and Coyne and Leeson (2004) and Smallbone and Welter (2002) apply the concepts in the context of a transition economy. Some progress towards empirical operationalization and assessment of the theory has also been made (Sobel 2008).

Before turning to our central issue, we want to draw attention to one of the core assumptions often overlooked when the Baumol typology is used. The problem is grasping the relevance of the unproductive category. In the proposed framework, entrepreneurial talent is viewed as a resource, and hence it is subject to scarcity of supply. Thus, even when entrepreneurial talent is channeled to unproductive activities that appear merely to entail a lump sum redistribution of resources, this necessarily must also involve an opportunity cost due to foregone productive potential. If unproductive activities are defined in terms of zero net effect on productivity, then this set of activities is very likely to be far too small to be of practical relevance. Henceforth, we simply merge Baumol's unproductive and destructive categories using the common label "non-productive".

\section{A reconsideration of Baumol's typology}

Although the main message of Baumol's (1990) paper offers important insights into a range of issues, we still believe that fundamental aspects of the theory need closer scrutiny. By uncovering some preconditions for a proper application of the Baumol typology, we also discuss some caveats that point towards our own contribution. In particular, it will be valuable to recognize clearly and to elaborate on the inconsistency in treating institutions solely as allocation mechanisms. However, before turning to this issue, we need to clarify our notion of efficiency.

Institutions in Baumol's theory play the role of allocating entrepreneurial talent. He therefore (implicitly) defines inefficient institutions in terms of allocation into less productive categories. However, the welfare evaluation that necessarily predates assignment into the typology should be conducted against the backdrop of a more general notion of inefficiency. 
To unfold its essential aspects, we will promulgate a highly stylized notion of efficiency. Productive activities, i.e., a market based provision of some (consumer) good or service, are simply assumed to be inherently efficient. Other, non-productive, activities are efficient or inefficient depending on whether they facilitate or hamper productive activities. Similarly, institutions are called efficient or inefficient depending on their positive or negative effect on productive activities.

It is important to realize that the different types of entrepreneurship all refer to a function, rather than an individual. The same individual could be engaged in both productive and nonproductive activities at the same time. To see why this is relevant, imagine a business owner who (in an innovative fashion) finds his way through the bureaucratic red-tape and finally acquires a production license. This is wasteful because, given first-best institutions, this entrepreneur could have put his energy into productive activities. The same conclusion cannot be drawn given the actual institutional setting that the business owner faces. Given that setting, it is clear that the non-productive activity was a prerequisite for subsequent productive activities. This might hold even if the acquired license is a monopoly license, in which case the prevailing institutions are probably even less efficient. Even in this case, non-productive entrepreneurship may be a way of breaking a bureaucratic deadlock preventing the license from being handed out at all. ${ }^{3}$

More generally, activities which at first glance appear to be obvious examples of nonproductive entrepreneurship routinely provide a second-best substitute for inefficient institutions. The two additional examples of corruption and the Mafia further illustrate this point.

It is a long debated issue whether corruption greases inefficient institutions or puts sand in efficient (or inefficient) institutions (Méon and Sekkat 2005). To be specific, inefficiency here refers to an overly bureaucratic governance structure and costs of red tape. Recent empirical studies show that the proposition that corruption reduces growth depends on the institutional setup. Méon and Weill (2008) and Klapper et al. (2006) find that the effect of inefficient

\footnotetext{
${ }^{3}$ In addition to reducing the negative implications of unproductive entrepreneurship, one can also hypothesize that there exists a positive effect from poorly functioning institutions. This could be the case where institutional barriers function as a gate-keeping mechanism, only letting the most talented entrepreneurs through. De Meza and Webb (1999), for instance, study a setting in which banks have incomplete information about the ability of heterogeneous entrepreneurs. They show that, under these assumptions, too many agents of lower ability obtain funding. Hence, credit rationing may serve a gate-keeping function against low quality projects.
} 
institutions is smaller when the level of corruption is high. ${ }^{4}$ Dreher and Gassebner (2007) find that corruption reduced the negative effect from inefficient institutions on entrepreneurial entry. These results indicate that, in some cases, it may be fruitful to view non-productive forms of entrepreneurship as a second-best productive response to suboptimal institutions.

Another example of entrepreneurship, which at first sight belongs to the non-productive category, is the Mafia. This is often mentioned as a prototypical example of violent extortion and appropriation of rents created by others. However, some scholars have argued that, under unstable institutional circumstances, or poor enforcement of property rights, organized crime can actually provide a substitute. Bandiera (2003) discusses the way in which the Sicilian Mafia thrived in a situation in which the old feudal system was reformed and landholdings redistributed to the private sector without the concomitant creation of public institutions for law enforcement. In a similar vein, Milhaupt and West (2000) argue that organized crime in Japan is a natural response to inefficient institutions. Organized crime is, in their words, "an entrepreneurial response to inefficiencies in the property rights and enforcement framework supplied by the state" (Milhaupt and West 2000, p. 43). Mafia activity in these Hobbesian situations might actually make the environment at least somewhat more predictable for the productive entrepreneur.

These examples show that the classification into productive, unproductive and destructive entrepreneurship is by no means straightforward, as Baumol himself recognizes in later writings (Baumol 1993). The Baumol typology does not, and was never meant to, give any guidance as to how to classify activities prior to making theoretical and empirical investigations. In particular, as the above examples show, possible second-best effects must be taken into account prior to classifying any activity.

The possibility that entrepreneurship provides second-best institutional solutions is interesting partly because of its significance in the real world, which is rife with imperfection and inefficiencies (Rodrik 2008). For our purposes, these activities also have an important theoretical implication. One cannot acknowledge that they, in effect, change the workings of formal institutions, but remain blind to the fact that they also change the social reward structure which, according to Baumol (1990), allocates entrepreneurial talent. Thus, without

\footnotetext{
${ }^{4}$ Of course, arguments have also been put forward against the "greasing the wheels" hypothesis. See Dreher and Gassebner (2007) for references.
} 
taking these effects into consideration, we cannot unambiguously determine how formal institutions will channel talent.

This problem never surfaces in Baumol (1990), because his purpose is to evaluate different institutional setups, not different entrepreneurial activities. Baumol's analysis is (implicitly) conducted against the backdrop of first-best institutions. It is noteworthy that Baumol (1990) discusses historical cases (Ancient Rome, China under the Sung Dynasty and England in the Late Middle Ages), in comparison to which modern Western institutions appear to be a reasonable proxy for first-best institutions. Hence, his analysis is consistent given its stated aim and the historical contexts he uses.

\section{Institutional entrepreneurship}

This section presents an alternative way of extending the notion of entrepreneurship. We argue that this extended notion has several distinct advantages compared to the Baumol typology.

\subsection{Entrepreneurial opportunities}

The possibility that non-productive entrepreneurship provides second-best solutions to institutional shortcomings points to a potential simultaneity problem, where the structure of payoffs which determines the allocation of entrepreneurial effort is itself affected by the outcome of the allocation. This logical circularity can only be resolved by looking more closely at the mechanisms behind the allocation of talent.

In Baumol's (1990) theory, the allocation mechanisms reside in the social reward structure, and there are no explicit feedback effects on the reward structure itself. To find fruitful ways out of this deadlock, let us ask the following question: "What gives incentives to entrepreneurs to provide second-best solutions?" The obvious answer is the potential to exploit profit opportunities, or, as we will call them, rents. The perhaps less obvious insight offered by this answer is that the institutional setup itself provides ample entrepreneurial opportunities. We will call attempts to exploit such opportunities institutional entrepreneurship, in contrast to business entrepreneurship where profits emanate from innovations in the production system. 
To highlight the similarity in objectives between the two types of entrepreneurship, we will henceforth say that they are both driven by opportunities to earn rents (rather than profit). We define rents as rates of return exceeding the risk-adjusted market rate of return or return in excess of a resource owner's opportunity cost (Tollison 1982). An alternative is to define rent as the part of the payment for a resource that has no effect on its supply (Alchian 1987). However, on this definition, it is implicitly assumed that rents exist exogenously, while entrepreneurship in our theory entails the creation and/or discovery of rents, thereby influencing the supply of entrepreneurship and other complementary factors of production. ${ }^{5}$ In order to avoid potential confusion, we abstain from calling the entrepreneur a rent seeker. The reason is that our definition of this term, which is in line with how it is used in much of the entrepreneurship literature, differs from its use in public choice (e.g., Tullock 1967; Buchanan 1980).

Entrepreneurs can secure the kind of unique resources needed to generate rents in several ways. Obvious examples include patents on valuable innovations, copyright, skillful implementation of tacit knowledge that cannot be imitated, and other entrepreneurial innovations that require a resource unavailable to potential competitors. ${ }^{6}$ In the broadest sense, the opportunities to earn a rent all involve the possession of some resource or technology that is unique or at least in very limited supply. ${ }^{7}$ It is important to realize that there is in principle no difference in this respect between the possession of a patent and the possession of knowledge of how to best avoid costs imposed by the tax code, or the possession of highly valuable production knowledge and valuable personal connections enabling one's firm to circumvent cumbersome regulations even if this requires paying kickbacks to government officials.

\footnotetext{
${ }^{5}$ See, e.g. Lewin and Phelan (2001), Alvarez (2007) and Henrekson (2007) for a discussion of entrepreneurial rents using the term as it is used here.

${ }^{6}$ Few rents last forever, and the durability varies substantially. Rents decay rapidly when they are based on activities that are easy to imitate and when the knowledge or skill is not embodied in a specific individual or organization. In such cases, the rents are often called "Marshallian" or quasi-rents. Normally, imitating competitors enter the market, which increases the supply and lowers the price. Alternatively, the original entrepreneur cuts prices in order to deter entry. According to calculations by Nordhaus (2004), entrepreneurs retain on average a mere two percent of the surplus generated by their activities. Institutional entrepreneurs also face competition, as other agents learn and adopt their methods of using institutions for their own benefit.

${ }^{7} \mathrm{We}$ are only interested in rents earned by entrepreneurial - i.e., innovative - activity. One may argue that some resources that are not in limited supply, such as guns, are often used to appropriate rent through sheer force. However, in most instances, such activities are not innovative, and therefore not entrepreneurial. When an innovative activity requires the use of weapons (e.g., the Mafia), it is not the weapons in themselves which are unique, but the fashion in which they are put to use (e.g., in building the organization). This said, it is still true that many new military instruments have been innovative in themselves.
} 
In our view, all entrepreneurial activities are directed towards the discovery or creation of opportunities to earn rents. Having said this, it is important to realize that the discovery or creation of opportunities to earn rents is not a sufficient condition for an activity to be classified as entrepreneurial. In the next section, we will connect to the notion of Schumpeterian equilibrium disruption, thereby requiring an entrepreneurial activity to be innovative and non-routine. Moreover, it is a natural simplification to limit the analysis to such entrepreneurs who are primarily engaged in business activities. Thus, we exclude the forms of entrepreneurship in which the agent has de jure decision power over institutions, often referred to as political entrepreneurship (e.g., Holcombe 2002; Wohlgemuth 2000).

\subsection{Foundations revisited}

The distinction made above between different kinds of entrepreneurship was, in contrast to Baumol (1990), drawn without reference to Schumpeter's notion of new combinations. Before turning to more concrete examples, it is advantageous to discuss how another aspect of Schumpeter's work may be useful in building a theory related to institutional entrepreneurship.

Modern entrepreneurship research draws mainly on two closely related aspects of Schumpeter (1934): The theory of new combinations and the theory of how the entrepreneur disturbs an existing equilibrium (the theory of creative destruction). The first theory describes what constitutes an innovation. In its most trivial (but clearly unfair) interpretation, this is a mere list of examples of entrepreneurial activities. By assigning the role of disrupter of equilibrium to the entrepreneur, the theory of new combinations explains how this disruption is accomplished.

The usefulness of the theory of new combinations is indisputable, but we find it even more fruitful to dwell on the second aspect, the entrepreneur as a disturber of an existing equilibrium. Baumol (1990) builds his typology on whether the innovation is a combination of productive or rent-seeking technologies. Our proposal is to separate different types of entrepreneurship based on where the entrepreneurial activity causes disruption. We extend the Schumpeterian notion of entrepreneurship to instances in which the entrepreneur disrupts the 
institutional equilibrium. Following this reasoning, institutional entrepreneurship ${ }^{8}$ emerges as an important object of study in a theory that involves endogenous institutions (cf. Acemoglu 2009).

One way to endogenize institutions is to consider a political economy growth system in which different types of political power shape the institutional setup, which will in its turn affect production processes (e.g., Acemoglu et al. 2005). An equilibrium can then be characterized in terms of the state of institutions as well as the state of the production system. ${ }^{9}$ In relation to such an equilibrium, we may talk about institutional or business entrepreneurship depending on where the disruption takes place (Douhan and Henrekson 2008).

An alternative to considering changes to formal institutions within a full-blown political economy system is to distinguish between codified and effective institutions. Examples of codified institutions include written laws, constitutions and procedural rules governing agents in the bureaucracy. When taking seriously the notion of institutions as rules that govern the behavior of agents, what matters is in most cases not the formal versions of institutions but how they work in practice, i.e., how they are implemented and enforced. We will refer to these as effective institutions. ${ }^{10}$

In the next section, we provide examples of the manner in which institutional entrepreneurship changes effective institutions. To see how that analysis differs from one building on a full-blown political economy system, consider the phenomenon of lobbying. In a modern society, this is probably the most obvious example of the way business interests try to influence the political sphere and formal institutions (Furlong and Kerwin 2005). ${ }^{11}$ Successful lobbying creates a rent when changes in codified institutions are translated into changes in effective institutions, for instance, by granting a firm a monopoly position.

\footnotetext{
${ }^{8}$ The term "institutional entrepreneurship" has previously been used by Daokui, Feng and Jiang (2006) in a sense that resembles but is less general than ours.

${ }^{9}$ This could include informal institutions such as norms, value systems and codes of conduct, even though these are unlikely to have much relevance given the fact they are seldom, if ever, shaped by the acts of single agents.

${ }^{10}$ This is comparable to the alignment of governance structures with transactions taking place at level 2 of the institutional hierarchy in Williamson (2000). Alternatively, if we consider the effects in a full-blown political economy system, it may be appropriate to see institutional entrepreneurship as taking place at level 3 (the institutional environment or the formal rules of the game).

${ }^{11}$ This type of entrepreneurship may be labeled political entrepreneurship and treated as a subgroup of institutional entrepreneurship. Political entrepreneurship does not per se require that the individual is engaged in commercial activities, but refers primarily to innovativeness and motivation within the political sphere (Holcombe 2002; Wohlgemuth 2000). Our definition of entrepreneurship abstracts from this subset.
} 
Institutional entrepreneurship directed towards effective institutions, in contrast, creates the rent more directly, for instance, by bribing a government official in order to earn special treatment which in effect gives the firm the same monopoly rights as laid down in official documents. $^{12}$

\subsection{Categories of institutional entrepreneurship}

Institutions can have costly as well as beneficial effects on productive activities, i.e., they can be more or less efficient. In this section, to avoid confusion with more or less efficiently implemented institutions, we will use the words beneficial and costly institutions. Entrepreneurial opportunities reside in the reduction of the impact of costly institutions or the strengthening of the effects of beneficial institutions. In both cases, rents can be earned by strengthening the position of a business entity (activity) owned by the same individual, in which case we may find it useful to talk about evasive entrepreneurship. Rents can also be earned from selling a service or contractual arrangement that reduces or strengthens the impact of a certain institution on another agent. We will focus our discussion on this latter kind of institutional entrepreneurship pertaining to market transactions.

One can imagine four basic ways of earning a rent by sale of a contract or a service to a third party: A, selling something that enhances the workings of beneficial, but poorly implemented, institutions; B, selling something that reduces the workings of harmful institutions; C, selling the withdrawal of a threat to strengthen harmful, but weakly implemented, institutions; D, selling the withdrawal of a threat to reduce the effect of beneficial institutions. ${ }^{13}$ Note that there exist two extreme cases. First, where and when an institution is perfectly implemented, rents can only be earned by reducing (or threatening to reduce) its effectiveness. Second, where and when an institution is mere window dressing with negligible effect, rents can only

\footnotetext{
${ }^{12}$ Lambsdorff (2002) questions the validity of treating lobbying as equally wasteful as corruption. However, although the distinction made in this paper between the two types of institutional entrepreneurship comes close to the distinction between corruption and lobbying, it is different in that we draw the distinction primarily with respect to whether codified or effective institutions are altered. There is no contradiction involved in assuming that corruption is used to wield influence over codified institutions and lobbying is directed towards changing effective institutions.

${ }^{13}$ Institutions may arise as market outcomes when there is no formal governance. Formal institutions are important to mitigate market failures due to incomplete or asymmetric information and commitment and enforcement problems. A lack of public provision of such institutions provides ample opportunities for private agents to offer alternative solutions. This is neatly summarized by Dixit (2004, p. 97): “[E]very economic problem is an economic opportunity. Someone who can solve the problem, turning the potential gains into actual ones, may be able to charge a fee for this service." This is a special case of A.
} 
be earned by increasing (or threatening to increase) its effectiveness. Our examples below relate to institutions that are in between these polar possibilities.

It is crucial to recognize that we do not claim that the activities of institutional entrepreneurs discussed below necessarily enhance social welfare. The words beneficial and harmful institutions refer rather to the effect that the institutions have on productive activities. Hence, our analysis is relevant to the micro level, i.e., the effect on individual productive agents. As illustrations of beneficial institutions, we will consider the protection of private property rights and the possession of production licenses or other deeds that grant the holder a monopoly right. Concrete examples of institutions that have potentially harmful effects on productive activities may include tax codes and ill-designed environmental legislation. ${ }^{14}$

A protective service provided by the Mafia is an example of the first kind of entrepreneurship (enhancing the workings of beneficial, but poorly implemented, institutions). As shown by Bandiera (2003) and Milhaupt and West (2000), such services can stabilize and make the environment of productive activities more predictable when the State is incapable of upholding law and order. The Mafia is then in possession of the unique resource of being able to provide protection of private property. The (informal) contract between the Mafia and the business provided with protection may to some extent be considered as an increased protection of property rights, yielding a rent to the Mafia.

Another example of the first kind of institutional entrepreneurship is when an agent manages to acquire some monopoly rights, i.e., a unique resource. This monopoly right can be sold or licensed to a productive agent in order for the latter to increase profit. The initial owner then receives a rent that accrues to his ability to identify the value of, and to obtain, the monopoly right in the first place. Note that, although an institutional setup that allows for monopoly licenses is likely to be inefficient from a social point of view, they are nonetheless still valuable for the individual productive agents.

Institutional entrepreneurship that reduces the effect of institutions harmful to the individual (but not necessarily to society) (B) is probably the most common. Tax consultants who come

\footnotetext{
${ }^{14}$ We only consider partial equilibrium effects in the sense that the firm does not take into consideration positive externalities of taxes (e.g., provision of educated labor and infrastructure) and environmental legislation (e.g., long-run positive effects of a conserved environment and a sustained supply of resources).
} 
up with innovative ways of lawfully evading taxes are a good example. A parallel logic applies to innovative ways of adjusting productive activity so that the cost-increasing effects of environmental standards are mitigated. The unique resources in these cases consist of superior knowledge of the way the rules laid down in the formal institutions can be sidestepped. Institutional entrepreneurship entails innovations, such as finding loopholes or inconsistencies in the regulatory framework. Such knowledge may be used to avoid detection by enforcing agencies or to appeal to if prosecuted.

Examples of institutional entrepreneurship of type $\mathrm{C}$ (withdrawal of a threat to strengthen harmful, but weakly implemented, institutions) include litigation and systematic economic fraud. Numerous kinds of litigation may be viewed as invoking some legal paragraph according to which the subject is (at least potentially) punishable. Depending on the severity of the sanction, the subject is willing to pay the institutional entrepreneur in order to avoid the charge. Tax codes and environmental legislation may be mentioned as obvious examples of institutions that may be invoked, as well as the class action suits leveled against entire industries in the US (smoking, asbestosis). The kinds of innovations made by the institutional entrepreneur are similar to the ones mentioned under type B.

We mentioned some types of acquisition of production licenses as examples of type A. Seen from the perspective of the bureaucrat or the official in charge of production licenses, there is also scope for entrepreneurship of type D (withdrawal of a threat to reduce the effect of beneficial institutions). This may occur when the bureaucrat threatens to withdraw a production or monopoly license. A firm possessing such licenses is, in many cases, willing to pay the bureaucrat in order to maintain their effectiveness. In highly corrupt countries, this type of threat may be part of the routine. Under other circumstances, entrepreneurial innovativeness is required to assess the value of the license and make the threat credible in a specific institutional setup.

The essential point of all these examples is that entrepreneurial activities should be evaluated against a well specified characterization of current conditions. The relevant context is the actual institutional setup, which, in all contemporary and historical instances, deviates from the first-best ideal. Hence, it is imperative to take into account the second-best effects. This certainly does not mean that institutional entrepreneurship is always welfare-improving from a social point of view. First, institutional entrepreneurship can (and, in many cases, does) 
impose an additional burden on the productive agent. Second, the net effect must include an objective assessment of which alternative productive activities the talent could instead have pursued.

To the extent that a welfare evaluation points to a negative welfare effect of institutional entrepreneurship, it is consistent to view it as an instance of Baumol's non-productive types of entrepreneurship. Given that these are, ex ante, merely a subset of the universe of activities we call institutional entrepreneurship, our suggested classification is arguably more general.

Moreover, our emphasis on second-best substitutes does not preclude the kind of evaluations of institutions that Baumol (1990) conducted. First-best institutions are still a relevant benchmark for such evaluations. However, these should be compared with the effective institutions rather than the formal institutions, and therefore the role of the effect of institutional entrepreneurs must be taken into consideration.

Finally, it is worth emphasizing that the fact that an activity is conducted in search of a rent is not a sufficient condition for it to be labeled entrepreneurial. If bribery is part of routine business conduct, it is not an entrepreneurial activity, but rather an integral part of an established institutional equilibrium. Similarly, if every interest group repeatedly employs more or less identical lobbying tactics, this is also part of an institutional equilibrium.

\section{Concluding remarks}

William Baumol's classic 1990 JPE paper opened up a new research tradition at the nexus of entrepreneurship and institutions. We have argued that, in order to take this field forward, it is necessary to take a second look at some of the foundations of Baumol's theory. Our intention has not been to attack the conclusions of Baumol and his followers, but to provide a more general theory that escapes some of the problems inherent in the typology used.

In particular, we have stressed that it is difficult within the boundaries of the typology to account for entrepreneurial activities which are second-best substitutes for inefficient institutions. These activities are important because they can alter institutions in ways that make them more efficient. This observation has far-reaching consequences for an evaluation of the welfare consequences of entrepreneurial activities. In particular, it clearly reveals that a 
welfare evaluation based solely on a comparison with first-best institutions may be highly misleading. Second, the possibility that entrepreneurial activities are second-best substitutes for inefficient institutions necessitates a reconsideration of the role of institutions as an allocation device.

We argue that a distinction between business and institutional entrepreneurship is better able to capture allocation effects of institutions. What these diverse types of entrepreneurship have in common is that it makes perfect sense to regard them as a search for rents. There is no difference in principle between earning a rent (a rate of return exceeding the risk-adjusted market rate of return) through the possession of a patent or by virtue of superior knowledge of how to exploit institutions to one's economic advantage.

Additional support for our proposed distinction can be mounted by going back to the main source of inspiration for Baumol: Joseph Schumpeter. Whereas Baumol draws on the concept of new combinations, we build rather on the concept of the entrepreneur as a disturber of equilibrium. This neatly connects the discussion of different types of entrepreneurship with a more general theory of the political economy of growth. An equilibrium in a full blown political economy model should always include both the production system and political and economic institutions. Both business and institutional entrepreneurs disturb this equilibrium, but do so in different parts of the model.

An important task for future research is to answer the question: Which features of institutions make them more amenable to innovative modification of their effectiveness? A result that emerges from our analysis is that such features would increase the susceptibility to institutional entrepreneurship. We hypothesize that institutional dimensions such as complexity and consistency are fruitful avenues for future research. To give some rationale for this hypothesis, consider the difference between countries with a highly complex tax code and those with a flat tax. Prima facie, our theory predicts that the former system breeds significantly more institutional entrepreneurship than the latter.

Our main conclusion is that entrepreneurial activities cannot be classified as socially wasteful without a contextual understanding of the way they interact with the institutional setup, and possibly remedy for some of its deficiencies. This is an extension of the argument put forward in Rodrik (2008) — institutional changes which at first sight look like improvement may in 
reality come into conflict with prevailing second-best solutions, thereby reducing the appropriateness of the institutional setup. Conversely: A ban on entrepreneurial activities that appear to be wasteful when gauged against a first-best institutional Nirvana may actually increase the cost of malfunctioning institutions. 


\section{REFERENCES}

Acemoglu, Daron (2009), Introduction to Modern Economic Growth, Princeton, NJ: Princeton University Press.

Acemoglu, Daron (1995), "Reward Structures and the Allocation of Talent", European Economic Review, 39(1), 17-33.

Acemoglu, Daron, Simon Johnson and James A. Robinson (2005), "Institutions as the Fundamental Cause of Long-run Growth", in Philippe Aghion and Steven Durlauf (eds.), Handbook of Economic Growth, Amsterdam: North-Holland.

Alchian, Armen A. (1987, "Rent", in John Eatwell, Murray Milgate and Peter Newman (eds.), The New Palgrave Dictionary of Economics. London: Macmillan.

Alvarez, Sharon A. (2007), "Entrepreneurial Rents and the Theory of the Firm", Journal of Business Venturing, 22(3), 427-442.

Bandiera, Oriana (2003), "Land Reform, the Market for Protection, and the Origins of the Sicilian Mafia: Theory and Evidence", Journal of Law, Economics and Organization, 19(1), 218-244.

Baumol, William J. (1990), “Entrepreneurship: Productive, Unproductive, and Destructive”, Journal of Political Economy, 98(5), 893-921.

Baumol, William J. (1993), Entrepreneurship, Management and the Structure of Payoffs, Cambridge, MA: MIT Press.

Baumol, William J. (2002), The Free-Market Innovation Machine: Analyzing the Growth Miracle of Capitalism, Princeton, NJ: Princeton University Press.

Buchanan, James M. (1980), "Rent Seeking and Profit Seeking," in James M. Buchanan and Gordon Tollison (eds.), Toward a Theory of the Rent Seeking Society, College Station, TX: Texas A\&M University Press.

Coyne, Christopher J. and Peter T. Leeson (2004), "The Plight of Underdeveloped Countries", Cato Journal, 24(3), 235-249.

Daokui Li, David, Junxin Feng and Hongping Jiang (2006), "Institutional Entrepreneurs", American Economic Review, 96(2), 358-362.

de Meza, David and David Webb (1999), "Wealth, Enterprise and Credit Policy", Economic Journal 109 (455), 153-163.

Desai, Sameeksha and Zoltan J. Acs (2007), "A Theory of Destructive Entrepreneurship", Jena Economic Research Papers No. 2007-085.

Dixit, Avinash K. (2004), Lawlessness and Economics, Princeton, NJ: Princeton University Press.

Douhan, Robin and Magnus Henrekson (2008), "Productive and Destructive Entrepreneurship in a Political Economy Framework", IFN Working Paper No 761, Research Institute of Industrial Economics.

Dreher, Axel and Martin Gassebner (2007), "Greasing the Wheels of Entrepreneurship? The Impact of Regulations and Corruption on Firm Entry”, CESifo Working Paper No. 2013.

Furlong, Scott R. and Cornelius M. Kerwin (2005), "Interest Group Participation in Rule Making: A Decade of Change", Journal of Public Administration Research and Theory, 15(3), 353-370.

Hall, Robert E. and Charles I. Jones (1999), "Why Do some Countries Produce so much more Output per Worker than Others?”, Quarterly Journal of Economics, 114(1), 83-116. 
Holcombe, Randall G. (2002), "Political Entrepreneurship and the Democratic Allocation of Resources", Review of Austrian Economics, 15(2/3), 143-159.

Henrekson, Magnus (2007), "Entrepreneurship and Institutions", Comparative Labor Law \& Policy Journal, 28(3), 717-742.

Jones, Charles I. (2001), "Was an Industrial Revolution Inevitable? Economic Growth over the very Long Run", Advances in Macroeconomics, 1(2), 1-43.

Klapper, Leora F., Luc Laeven and Raguram Rajan (2006), "Business Environment and Firm Entry: Evidence from International Data", Journal of Financial Economics, 82(3), 591-629.

Lambsdorff, Johann G. (2002), “Corruption and Rent Seeking”, Public Choice, 113(1), 97-125.

Lewin, Peter and Steven E. Phelan (2001), "Rents and Resources: A Market Process Perspective", in Nicolai J. Foss and Peter G. Klein (eds.), Entrepreneurship and the Firm, Cheltenham: Edward Elgar.

Méon, Pierre-Guillaume and Khalid Sekkat (2005), "Does Corruption Grease or Sand the Wheels of Growth?", Public Choice, 122(1-2), 69-97.

Méon, Pierre-Guillaume and Laurent Weill (2008), "Is Corruption an Efficient Grease?" LaRGE Working Paper 2008-06, Université Louis Pasteur, Strasbourg.

Milhaupt, Curtis J. and Mark D. West (2000), “The Dark Side of Private Ordering: An Institutional and Empirical Analysis of Organized Crime", University of Chicago Law Review, 67(1), 41-98.

Minniti, Maria (2008), "The Role of Government Policy on Entrepreneurial Activity: Productive, Unproductive, or Destructive?" Entrepreneurship Theory and Practice, 32(5), 779-790.

Murphy, Kevin M., Andrei Shleifer and Robert W. Vishny (1991), "The Allocation of Talent: Implications for Growth", Quarterly Journal of Economics, 106(2), 503-530.

Nordhaus, William D. (2004), "Schumpeterian Profits in the American Economy: Theory and Measurement”, NBER Working Paper No. 104333.

North, Douglass C (1990), Institutions, Institutional Change, and Economic Performance. Cambridge: Cambridge University Press.

Rodrik, Dani (2008), “Second-best Institutions”, American Economic Review, 98(2), 100-104.

Rodrik, Dani, Arvind Subramanian and Francesco Trebbi (2004), "Institutions Rule: The Primacy of Institutions over Geography and Integration in Economic Development", Journal of Economic Growth, 9(2), 131-165.

Schumpeter, Joseph A. (1934), The Theory of Economic Development, Cambridge, MA: Harvard University Press.

Smallbone, David and Friederike Welter (2002), "The Distinctiveness of Entrepreneurship in Transition Economies", Small Business Economics, 16(4), 249-262.

Sobel, Russell S. (2008), "Testing Baumol: Institutional Quality and the Productivity of Entrepreneurship", Journal of Business Venturing, 23(6), 641-655..

Tollison, Robert D. (1982), "Rent Seeking: A Survey”, Kyklos, 35(4), 575-602.

Tullock, Gordon (1967), "The Welfare Costs of Tariffs, Monopolies, and Theft", Western Economic Journal, 5(2), 224-232.

Williamson, Oliver E. (2000), "The New Institutional Economics: Taking Stock, Looking Ahead", Journal of Economic Literature, 38(3), 595-613.

Wohlgemuth, Michael (2000), "Political Entrepreneurship and Bidding for Political Monopoly", Journal of Evolutionary Economics, 10(3), 273-295. 